\title{
Hot water disinfection treatment to eliminate Neonectria ditissima latent infections in apple scion wood
}

\author{
N.T. Amponsah ${ }^{1}$, B.M. Fisher ${ }^{1}$ M. Walter ${ }^{2}$, L. Frijters ${ }^{3}$, D.I. Hedderley ${ }^{4}$ and \\ R.W.A. Scheper ${ }^{1}$ \\ ${ }^{1}$ The New Zealand Institute for Plant \& Food Research Limited (PFR), \\ Private Bag 1401, Havelock North 4130, New Zealand \\ ${ }^{2}$ PFR, Old Mill Road, RD 3 Motueka 7198, New Zealand \\ ${ }^{3}$ HAS University of Applied Sciences, 's-Hertogenbosch, the Netherlands \\ ${ }^{4}$ PFR, Batchelar Road, Palmerston North 4474, New Zealand \\ Corresponding author: nicholas.amponsah@plantandfood.co.nz
}

\begin{abstract}
The European canker pathogen, Neonectria ditissima, can be transmitted by apple scion wood into newly developing trees following grafting or budding resulting in disease development and progression. An in vitro hot water treatment showed that both conidia and mycelium of $N$. ditissima can be killed when placed into water at $50^{\circ} \mathrm{C}$ for $\geq 5 \mathrm{~min}$. However, diseased scion wood required $\geq 15$ min disinfection at the same temperature to eliminate all internal pathogens including $N$. ditissima. At this temperature and time duration, no mycelium growth was observed after 2 weeks incubation of cut pieces of the disinfected tissues on apple sap amended water agar. Although the treatment was $100 \%$ effective at eliminating some identified and non-specific pathogens, visual assessment of both the scion and rootstock viability and vigour six months after the hot water treatment showed that $98 \%$ of the rootstocks and scions failed to grow and develop.
\end{abstract}

Keywords: graftwood, budwood, scion wood, propagation, nursery, Neonectria ditissima, Nectria galligena, Neonectria galligena, disinfection, hot water treatment, European canker.

\section{INTRODUCTION}

European canker, caused by Neonectria ditissima, is an economically important disease in high rainfall apple-growing areas of New Zealand. There is currently no known resistance to the pathogen and the disease can be spread through propagation (McCracken et al. 2003), including scion wood, rootstocks and nursery trees. While it is best to collect and use scion wood from trees that are not infected, it is not always possible to do so as latent infections may be missed. Symptoms on infected trees may also be missed and uninfected source trees may not be available to meet the scion wood needs of the grower.

An alternative technique such as hot water disinfection of scion wood to ensure Neonectria ditissima-free propagation material would 
substantially help to control the spread of the disease. Hot water disinfection has been proposed for the control of bacterial plant pathogens, for example Erwinia carotovora in potato tubers and Erwinia chrysanthemi (Mackay \& Shipton 1983; Robinson \& Foster 1987), Agrobacterium tumefaciens in grapevine cuttings (Burr et al. 1989; Bazzi et al. (1991), Clavibacter michiganensis pv. michiganensis in tomato seeds (Fatmi et al. 1991), and Xanthomonas campestris pv. malvacearum in cotton seeds (Honervogt \& Lehmann-Danzinger 1992). It is a robust, reliable and accepted treatment for eliminating pests (insects, nematodes) and pathogens (phytoplasma, bacteria, fungi) from nursery plant propagation material in many crops (EFSA 2015). Although many studies have been carried out to determine the optimal temperature for $N$. ditissima infection in field conditions, very little is known about spore thermotolerance. The objectives of this study were: (1) To investigate the relationship between time and temperature on the survival of conidia, ascospores and mycelium of $N$. ditissima in vitro; and (2) To examine the effects of different temperatures on the viability of apple scion wood used for propagation.

\section{MATERIALS AND METHODS Neonectria ditissima isolates and spore production}

Eight isolates of N. ditissima (RS324p, RS304p1, RS305p, RS307p1, RS340p1, RS347c, MW14c, ICMP14098) were used in this study, as described by Scheper et al. 2014. Conidia were produced on modified Matsushima agar (MM) at $20^{\circ} \mathrm{C}$ under near-UV light in non-vented Petri dishes, as described by Scheper et al. 2014. Ascospores were produced by crossing RS324p with the other seven isolates using a method adapted from Scheper \& Pauli (2013), using glucose yeast agar and sterile 'Royal Gala' wood pieces placed on the agar. Mycelium was produced by growing all isolates on potato dextrose agar (PDA, Difco) for 7 days at $20^{\circ} \mathrm{C}$ in the dark. Each plate was seeded with five colonies of an isolate using $5 \mathrm{~mm}$ diameter mycelial plugs.

\section{Experiment 1: In vitro hot water treatments (HWT) of mycelial agar plugs}

To determine the effect of the HWT on in vitro mycelium growth, five 1-week old $N$. ditissima mycelial colonies were covered with sterile distilled water at $50^{\circ} \mathrm{C}$, and the lids replaced and sealed tightly with Parafilm ${ }^{\text {Tx }}$ to prevent leakage. The Petri dishes were then immersed in the hot water bath (Julabo 20B) at $50^{\circ} \mathrm{C}$ for $25 \mathrm{~min}$. There were three replicate PDA plates per isolate. After the HWT, the water was drained and the fungal colonies air-dried for $2 \mathrm{~h}$ in a laminar flow cabinet. The plates were then incubated at $20^{\circ} \mathrm{C}$ for $1-3$ weeks and the HWT mycelial colony growth was compared with corresponding non-HWT samples (control).

\section{Experiment 2: In vitro HWT of conidia and ascospores suspension}

To determine the effect HWT on conidia (isolate RS324p) and ascospores (mixed from the ten crosses), conidia were harvested in sterile distilled water at $20^{\circ} \mathrm{C}$ by flooding the plates. The ascospores were harvested by removing perithecia with a sterile scalpel and placing them in sterile distilled water. The spores were allowed to naturally dehisce. The ascospore suspension was pipetted into a clean McCartney bottle when the perithecia had sunk to the bottom. The conidial suspension was adjusted to a final concentration of $9 \times 10^{4}$ conidia/ml and the ascospore suspension to $2 \times 10^{5}$ ascospores $/ \mathrm{ml}$ using a haemocytometer. The conidial and ascospore suspensions were aliquotted into $1.5 \mathrm{ml}$ micro centrifuge tubes with a volume of $300 \mu \mathrm{l}$ per tube and incubated at 20, 30, 35, 40,45 and $50^{\circ} \mathrm{C}$ in water baths for periods of $5,15,30,60,120,240 \mathrm{~min}$ and $24 \mathrm{~h}$ (specific times and temperatures are shown in Table 1). At $50^{\circ} \mathrm{C}$, the conidia were only incubated for 5,15 and $30 \mathrm{~min}$. The ascospore suspensions were incubated at the same temperatures for the same time intervals, except $240 \mathrm{~min}$ was replaced by $180 \mathrm{~min}$. Viability of the conidia and ascospores was determined by counting germinated spores in $20 \mu \mathrm{l}$ droplets on glass 
slides after $24 \mathrm{~h}$ in a humidity chamber at $22^{\circ} \mathrm{C}$. Colony forming units were counted by diluting a $20 \mu \mathrm{l}$ subsample 15 -fold and spreading them onto PDA (two plates per treatment, $150 \mu \mathrm{l} /$ plate) and then incubating them for 1 week at $20^{\circ} \mathrm{C}$. The germination rate and the number of colonies were determined in duplicate for each tube.

\section{Experiment 3: Hot water treatments of naturally- and artificially-infected non- dormant scion wood}

A sample of 800 naturally-infected non-dormant 'Braeburn' scion wood shoots was collected in November 2014 from a commercial orchard. Every tree in this orchard had multiple European canker lesions and all shoots collected from these trees had one or more canker lesions on them. A $30 \mathrm{~cm}$ segment without a visible lesion was removed from each of these 800 scion wood shoots, and stored for 11 weeks at $4^{\circ} \mathrm{C}$ in the dark in a plastic bag wrapped in brown paper.

In February 2015, half of the 800 scion wood segments were placed at room temperature to warm up before being fully submerged in an $N$. ditissima conidial suspension $\left(1 \times 10^{4}\right.$ conidia/ $\mathrm{ml}$ ) for $3 \mathrm{~h}$, after which the segments were incubated at $20^{\circ} \mathrm{C}$ under high humidity for 3 days to ensure effective conidial attachment and penetration of the scion wood. These scion wood segments are referred to as "artificially-infected". The remaining 400 scion wood segments are referred to as "naturally-infected". No rootstocks were treated in this experiment.

After the 3-day incubation period, both the naturally- and artificially-infected scion wood segments were fully submerged in a hot water bath (Julabo 20B) and incubated at 30, 35, 40, 45, 50, 55, 60 and $65^{\circ} \mathrm{C}$ for periods of $10,30,45,60$ and 120 min (specific times and temperatures are shown in Table 2). The scion wood segments were immersed in $6 \mathrm{~L}$ of water in an $8 \mathrm{~L}$ capacity water bath that was preheated to the required temperature. The scion wood segments were totally immersed in bundles of ten at each temperature and time combination. A metal rod was placed across the bundles to ensure they remained fully immersed. The target water temperature was maintained and monitored to within $\pm 1^{\circ} \mathrm{C}$ by watching a mercury thermometer in the water bath. After each temperature and time treatment, the scion wood segments in bundles were removed from the hot water and immediately submerged in water held at room temperature for $5 \mathrm{~min}$ to cool them quickly.

The treated scion wood segments were then wrapped in wet paper towels and kept at $4^{\circ} \mathrm{C}$ for 3 days in the dark, after which the top and bottom pieces $(2.5 \mathrm{~cm}$ each side) of each scion wood segment were removed with a sterile scalpel and visually observed for any change in wood colour. These pieces were then cut into ten $2-3 \mathrm{~mm}$ sections which were plated onto apple sap amended water agar (ASAWA), ten sections per plate, as described by Amponsah et al. (2014). They were incubated at room temperature (approximately $18-20^{\circ} \mathrm{C}$ ) for 2 weeks to encourage mycelial growth of $N$. ditissima and other pathogens.

The HWT naturally-infected scion wood segments (now $25 \mathrm{~cm}$ long) were then used for grafting. A $7 \mathrm{~cm}$ piece was cut from each of the HWT naturally-infected scion wood segments and grafted separately onto 'M9' rootstocks, ten for each temperature-time combination. The grafted plants were placed into sawdust for callusing for 5 weeks before planting in the field in March 2015. Standard management practices and visual plant health and disease assessments were carried out. Scion wood that were artificially-infected and HWT were not used for grafting but only assessed for N. ditissima survival.

\section{Experiment 4: Hot water treatments of dormant scion wood and rootstocks}

The experimental design of Experiment 4 took into consideration the results of Experiment 3. The dormant scion wood and rootstocks (infection status unknown) were HWT at one temperature $\left(50^{\circ} \mathrm{C}\right)$ and immersed for 15 or 25 min. One hundred and ten 'M793' rootstocks and 50 scion wood shoots $(30 \mathrm{~cm})$, sufficient to graft all rootstocks, were obtained from a commercial nursery in the Nelson region in July 2015. One 
set of 55 rootstocks ( $N$. ditissima infection status unknown) was immersed in water at $50^{\circ} \mathrm{C}$ for $15 \mathrm{~min}$, and the second set of 55 rootstocks was also immersed in water at $50^{\circ} \mathrm{C}$ but for $25 \mathrm{~min}$. The same temperature and times were also used for the disinfection of two sets of 25 scion wood shoots ( $N$. ditissima infection status unknown). In addition, another 20 dormant scion wood shoots were artificially-infected with $N$. ditissima as described before in the previous experiment. Five of these artificially-infected scion wood shoots were HWT for $25 \mathrm{~min}$ and another five were HWT for $15 \mathrm{~min}$. The remaining ten were not-HWT and served as a positive control. For the temperature and time treatments, the respective scion wood shoots and rootstocks were immersed in the hot water in bundles of 10 to 15 and at $50^{\circ} \mathrm{C}$ for 15 or 25 min. After each HWT, the scion wood and rootstocks were cooled as previously described. After cooling, five rootstocks and five scion wood shoots for each HWT immersion time were randomly selected for pathogen isolation. All

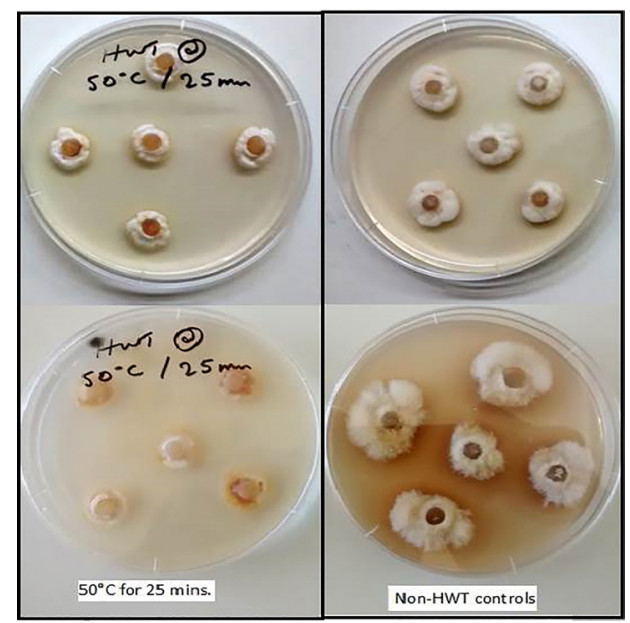

Figure 1 Neonectria ditissima mycelial agar plugs incubated on potato dextrose agar at $20^{\circ} \mathrm{C}$. Top left hot water-treated (HWT) mycelial agar plugs; top right non-HWT mycelia agar plugs; bottom left shows 1 week after HWT and bottom right shows 1 week after non-HWT.
20 artificially infected positive controls (HWT and not) were also processed for pathogen isolation. The rootstocks and scion wood were air-dried in a laminar flow cabinet, and ten sections (8-9 mm) were cut and placed cut surface down onto ASAWA and PDA plates. Each Petri dish had ten cut pieces and there were four replicate plates per treatment. The plates were incubated at room temperature $\left(18-20^{\circ} \mathrm{C}\right)$ for 2 weeks. The remaining $100 \mathrm{HWT}$ rootstocks and $40 \mathrm{HWT}$ scion wood shoots were wrapped in wet paper towels and kept at $4^{\circ} \mathrm{C}$ overnight in the dark before sending them to the nursery for grafting in July 2015. HWT scion wood was grafted onto HWT rootstocks that had had the same immersion time. No grafting was done with any of the artificially-infected scion wood. All grafting was routinely carried out by commercial nursery staff as part of their normal grafting work. All 100 HWT grafted plants (50 each for the 15 and $25 \mathrm{~min}$, respectively), together with 100 non-HWT grafted plants provided by the nursery staff, were put into sawdust for callusing prior to

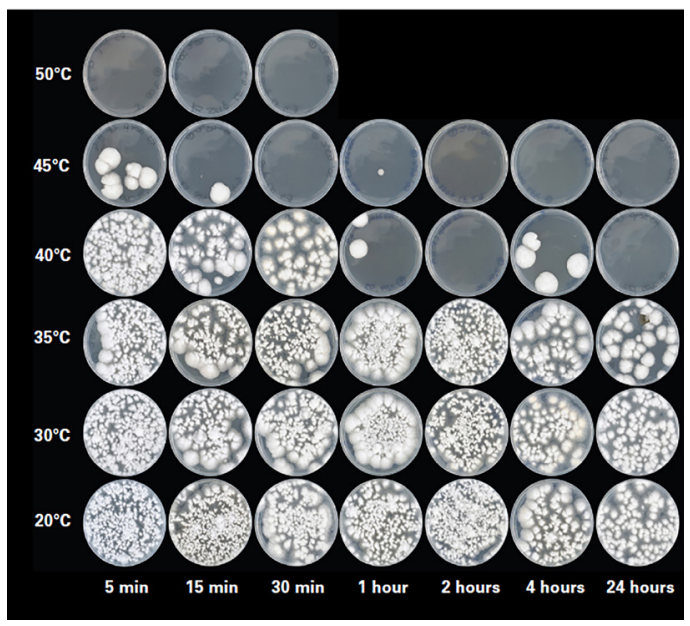

Figure 2 Conidial growth on potato dextrose agar after exposure to six temperatures $\left(20-50^{\circ} \mathrm{C}\right)$ for up to 24 hours. Image shows colony growth after 2 weeks of incubation at $20^{\circ} \mathrm{C}$. 
planting them out in the field. In January 2016, 6 months after planting, visual assessments were made of plant vigour and expression of disease in the HWT samples and non-HWT plants.

\section{RESULTS}

\section{Experiment 1: In vitro HWT of mycelial agar plugs}

The 1-week-old mycelial colonies that were treated for $25 \mathrm{~min}$ at $50^{\circ} \mathrm{C}$ and then incubated for 1-3 weeks at $20^{\circ} \mathrm{C}$ stopped growing and showed signs of disintegration. The non-HWT colonies grew profusely during the same period (Figure 1).

\section{Experiment 2: In vitro HWT of conidia and ascospores suspension}

Exposure to 20 and $30^{\circ} \mathrm{C}$ for up to $24 \mathrm{~h}$ did not affect the conidial germination rate or the number of colonies on PDA, but exposure to higher temperatures was more detrimental as treatment duration increased (Table 1, Figure 2). Exposure to $50^{\circ} \mathrm{C}$ killed all spores exposed for $5 \mathrm{~min}$. Ascospore germination rates after exposure to different temperatures for varying lengths of time mirrored the conidial germination rates: exposure to higher temperatures became more detrimental as the exposure time increased.

To model the germination data a logistic regression was used; a quadratic model using (log) exposure time and temperature best explained the relationship between conidial germination and exposure time (Figure 3a). The average germination rate after exposure to the different temperatures differed significantly $(\mathrm{P}<0.05)$, as did the response curve over time between the different temperatures $(\mathrm{P}<0.05)$. For colony growth, a generalised linear model with a Poisson distribution, predicting number of colonies using a quadratic model using (log) exposure time and temperature was fitted (Figure 3b). The effect of temperature and exposure time was statistically significant $(\mathrm{P}<0.05)$ in all tests.

\section{Experiment 3: Hot water treatments of naturally- and artificially-infected non- dormant scion wood}

HWT of scion wood with temperature and time combinations ranging from 30 to $65^{\circ} \mathrm{C}$ for 60

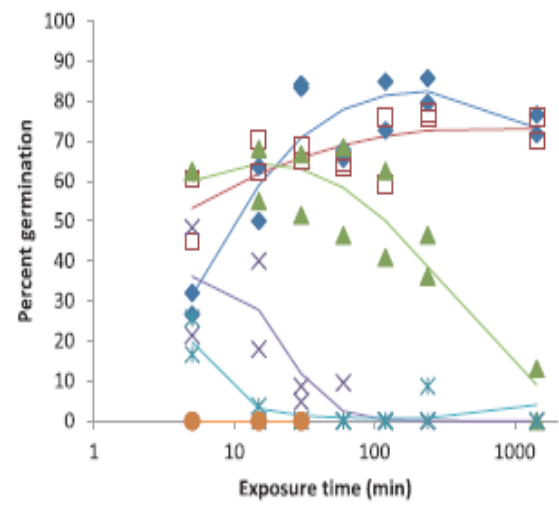

a

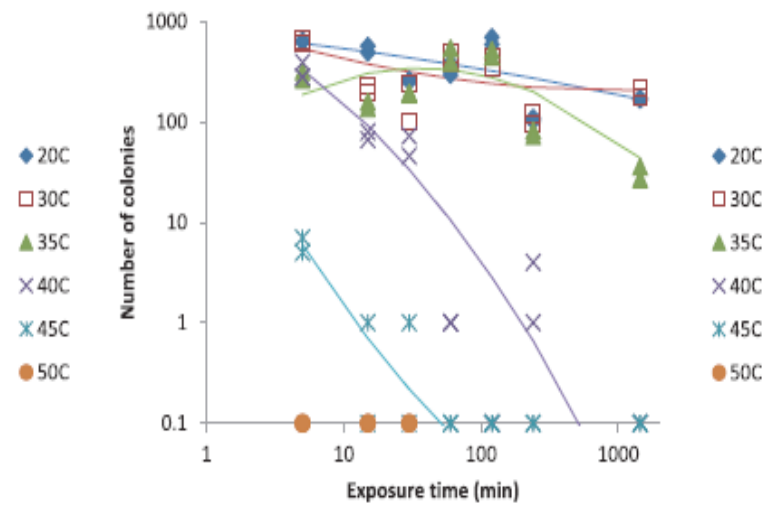

b

Figure 3 Conidial viability after exposure to six temperatures $\left(20-50^{\circ} \mathrm{C}\right)$ for up to 24 hours. Viability was determined as a) the germination rate on glass microscopy slides after $24 \mathrm{~h}$ in a humidity chamber at $22^{\circ} \mathrm{C}$, and b) the number of colonies on potato dextrose agar after 1 week at $20^{\circ} \mathrm{C}$. A logistic regression of germination rate and a Poisson generalized linear model of the number of colonies against exposure time, with time on a log scale, is shown. 
Table 1 Neonectria ditissima conidial viability after exposure to six temperatures for up to 24 hours. Viability was determined as the average germination rate on glass microscopy slides after $24 \mathrm{~h}$ in a humidity chamber at $22^{\circ} \mathrm{C}$.

\begin{tabular}{cccccccc}
\hline $\begin{array}{c}\text { Temperature } \\
\left({ }^{\circ} \mathbf{C}\right)\end{array}$ & $\mathbf{5} \mathbf{~} \mathbf{~ i n}$ & $\mathbf{1 5}$ & $\mathbf{3 0}$ & $\mathbf{1 ~ h}$ & $\mathbf{2 ~ h}$ & $\mathbf{4} \mathbf{~ h}$ & $\mathbf{2 4} \mathbf{~ h}$ \\
& & $\mathbf{m i n}$ & $\mathbf{m i n}$ & & & & \\
\hline $\mathbf{2 0}$ & 29 & 57 & 84 & 67 & 83 & 83 & 74 \\
$\mathbf{3 0}$ & 59 & 66 & 66 & 64 & 68 & 76 & 73 \\
$\mathbf{3 5}$ & 62 & 62 & 59 & 57 & 52 & 41 & 7 \\
$\mathbf{4 0}$ & 35 & 29 & 7 & 5 & 0 & 0 & 0 \\
$\mathbf{4 5}$ & 21 & 2 & 0 & 0 & 0 & 4 & 0 \\
$\mathbf{5 0}$ & 0 & 0 & 0 & - & - & - & - \\
\hline
\end{tabular}

Table 2 Temperature-time matrix profile to determine the thermal tolerance of Neonectria ditissima and other latent pathogens in infected scion wood and scion wood susceptibility after hot water treatments in a constant temperature water bath set at $30-65^{\circ} \mathrm{C}$ in Experiment 3. (W+ stands for unstained scion wood, $\mathrm{W}$ - for stained scion wood, $\mathrm{P}+$ for viable latent pathogens, and $\mathrm{P}$ - for non-viability of latent pathogens).

\begin{tabular}{|c|c|c|c|c|c|c|c|c|}
\hline \multirow[b]{2}{*}{ Time } & \multicolumn{8}{|c|}{ Temperature $\left({ }^{\circ} \mathrm{C}\right)$} \\
\hline & 30 & 35 & 40 & 45 & 50 & 55 & 60 & 65 \\
\hline $10 \mathrm{~min}$ & $\begin{array}{l}\mathrm{W}+ \\
\mathrm{P}+\end{array}$ & $\begin{array}{c}\mathrm{W}+ \\
\mathrm{P}+\end{array}$ & $\begin{array}{c}\mathrm{W}+ \\
\mathrm{P}+\end{array}$ & $\begin{array}{l}\mathrm{W}+ \\
\mathrm{P}+\end{array}$ & $\begin{array}{l}\mathrm{W}+ \\
\mathrm{P}+\end{array}$ & $\begin{array}{c}\mathrm{W}+ \\
\mathrm{P}+\end{array}$ & $\begin{array}{c}\mathrm{W}+ \\
\mathrm{P}+\end{array}$ & $\begin{array}{l}\mathrm{W}+ \\
\mathrm{P}+\end{array}$ \\
\hline $30 \mathrm{~min}$ & $\begin{array}{l}\mathrm{W}+ \\
\mathrm{P}+\end{array}$ & $\begin{array}{c}\mathrm{W}+ \\
\mathrm{P}+\end{array}$ & $\begin{array}{l}\mathrm{W}+ \\
\mathrm{P}+\end{array}$ & $\begin{array}{l}\mathrm{W}+ \\
\mathrm{P}+\end{array}$ & $\begin{array}{c}\text { W+ } \\
\text { P- }\end{array}$ & $\begin{array}{l}\text { W- } \\
\text { P- }\end{array}$ & $\begin{array}{l}\text { W- } \\
\text { P- }\end{array}$ & $\begin{array}{l}\text { W- } \\
\text { P- }\end{array}$ \\
\hline $45 \mathrm{~min}$ & $\begin{array}{l}\mathrm{W}+ \\
\mathrm{P}+\end{array}$ & $\begin{array}{c}\mathrm{W}+ \\
\mathrm{P}+\end{array}$ & $\begin{array}{l}\mathrm{W}+ \\
\mathrm{P}+\end{array}$ & $\begin{array}{l}\text { W- } \\
\text { P- }\end{array}$ & $\begin{array}{l}\text { W- } \\
\text { P- }\end{array}$ & $\begin{array}{l}\text { W- } \\
\text { P- }\end{array}$ & $\begin{array}{l}\text { W- } \\
\text { P- }\end{array}$ & $\begin{array}{l}\text { W- } \\
\text { P- }\end{array}$ \\
\hline $60 \mathrm{~min}$ & $\begin{array}{l}\text { W- } \\
\text { P- }\end{array}$ & $\begin{array}{l}\text { W- } \\
\text { P- }\end{array}$ & $\begin{array}{l}\text { W- } \\
\text { P- }\end{array}$ & $\begin{array}{l}\text { W- } \\
\text { P- }\end{array}$ & $\begin{array}{l}\text { W- } \\
\text { P- }\end{array}$ & $\begin{array}{l}\text { W- } \\
\text { P- }\end{array}$ & $\begin{array}{l}\text { W- } \\
\text { P- }\end{array}$ & $\begin{array}{l}\text { W- } \\
\text { P- }\end{array}$ \\
\hline
\end{tabular}

Table 3 The total number of scion wood that survived from 10 grafted plants after hot water treatment at different temperature-time combinations of naturally-infected non-dormant apple scion wood to achieve heat disinfection in Experiment 3.

\begin{tabular}{cccccccc}
\hline & \multicolumn{7}{c}{ Temperature $\left({ }^{\circ} \mathbf{C}\right)$} \\
\cline { 2 - 7 } Time (Min) & 30 & 35 & 40 & 45 & 50 & 55 & 60 \\
\hline $\mathbf{1 0}$ & $3 / 10$ & $3 / 10$ & $3 / 10$ & $4 / 10$ & $3 / 10$ & $3 / 10$ & $2 / 10$ \\
$\mathbf{3 0}$ & $2 / 10$ & $2 / 10$ & $1 / 10$ & $2 / 10$ & $0 / 10$ & & \\
$\mathbf{4 5}$ & $1 / 10$ & $2 / 10$ & $2 / 10$ & & & & \\
\hline
\end{tabular}

min and longer; $45^{\circ} \mathrm{C}$ for $45 \mathrm{~min}$ and longer; and $55-65^{\circ} \mathrm{C}$ for $30 \mathrm{~min}$ and longer eliminated all pathogens including $N$. ditissima from the scion wood (Table 2). However, these temperature and time combinations also caused internal browning of the tissues, suggesting the plant cells had been destroyed by the heat. The only temperature and time combination that was effective at eliminating latent infections with no visible browning of internal tissues was $50^{\circ} \mathrm{C}$ for $30 \mathrm{~min}$ (Table 2). However, when these HWT naturally-infected scion wood pieces $(7 \mathrm{~cm})$ were grafted onto nonHWT rootstocks, all ten grafted plants failed to establish a graft union and died (Table 3 ). 


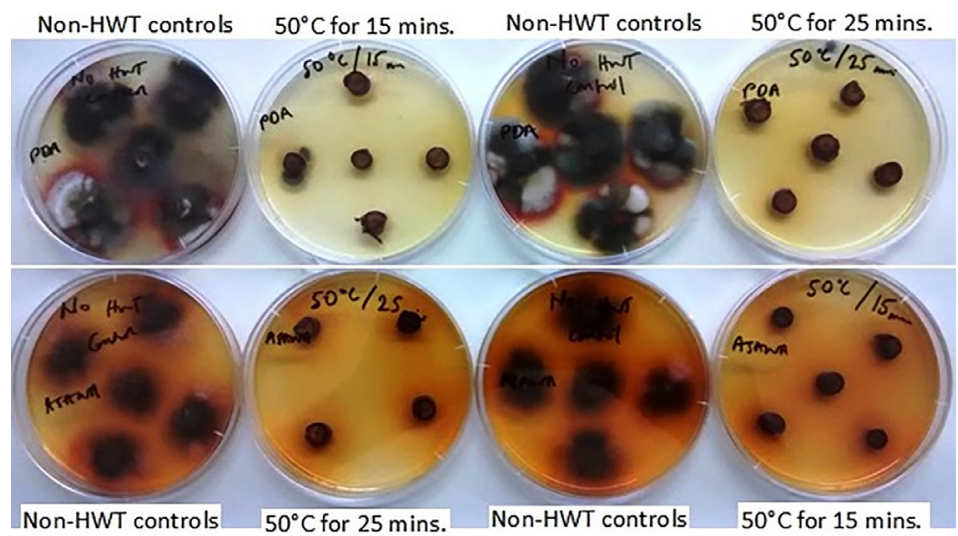

Figure 4 Fungal colonies emerging from hot water treated (HWT) and non-HWT apple scion wood artificially infected with Neonectria ditissima, 2 weeks after incubation at $20^{\circ} \mathrm{C}$ (Above: colony growth on potato dextrose agar; below: colony growth on apple sap amended water agar).

Assessment of the scion wood pieces incubated on ASAWA at room temperature for 2 weeks after HWT for N. ditissima and other some pathogens that may have been present showed that hot water treatments for scion wood at 30 to $65^{\circ} \mathrm{C}$ for $10 \mathrm{~min}$; 30 to $50^{\circ} \mathrm{C}$ for $30 \mathrm{~min}$ and 30 to $40^{\circ} \mathrm{C}$ for $45 \mathrm{~min}$ did not result in any internal browning (Table 2), but these temperature and time combinations did not eliminate any of the pathogens from the wood (Table 2). Neonectria ditissima, Fusarium species, Alternaria species or other unidentified fungal species, or a combination of two or more of these species, were isolated from every section of both the naturally- and artificially-infected HWT scion wood incubated on ASAWA. One hundred and fifty naturally-infected scion wood pieces from such temperature-time combinations did not show any visible internal browning when cross sections were made. When these scion wood pieces were grafted onto non-HWT rootstocks, only 33 plants developed shoots although not as vigorous as the non-HWT grafted controls. Overall, 117 failed to form any union with the rootstocks and died (Table 3 ), although their rootstocks grew normally with new shoots. Naturally-infected scion wood treated at temperature and time combinations ranging from 30 to $65^{\circ} \mathrm{C}$ for 60 to $120 \mathrm{~min} ; 55$ to $60^{\circ} \mathrm{C}$ for 30 to $45 \mathrm{~min}$; and 45 to $60^{\circ} \mathrm{C}$ for $45 \mathrm{~min}$ were not grafted due the severity of internal browning of the scion wood observed after sectioning.

\section{Experiment 4: Hot water treatments of dormant scion wood and rootstocks}

HWT using $50^{\circ} \mathrm{C}$ and reduced immersion times of 15 and $25 \mathrm{~min}$ for both dormant rootstock and scion wood were successful. These treatments eradicated most of the internal and external pathogens, as little or no mycelium grew from the cut sections when incubated on PDA or ASAWA for up to 2 weeks. In contrast, cut pieces from the non-HWT but inoculated scion wood, yielded many different types of fungi when incubated on PDA or ASAWA for up to 2 weeks (Figure 4). No internal discoloration differences were observed when the HWT scion wood were compared with the non-HWT scion wood after cutting the wood into cross and longitudinal sections, suggesting that disinfection can be achieved with hot water at $50^{\circ} \mathrm{C}$ and at immersion times between 15 and $25 \mathrm{~min}$. However, after grafting and planting in the field, only 1 plant each from the 15 and 25 min treatments ( 100 plants in total) developed shoots. The HWT rootstocks were also found to be unhealthy with very few small 
shoots, or no shoots at all emerging. However, the non-HWT controls grew normally with shoots emerging from both scion wood and rootstocks.

\section{DISCUSSION}

This study showed that HWT exceeded the thermal tolerance level of apple propagation material at temperatures required to control $N$. ditissima fungus. None of the temperature-time combinations tested in the HWT was tolerated by non-dormant scion wood which was shown by the large numbers of failed grafts. Similarly, dormant scion wood and 'M793' rootstocks did not tolerate $\mathrm{HWT}$ at $50^{\circ} \mathrm{C}$.

Neonectria ditissima mycelium colonies growing on PDA, and conidia and ascospores suspension into hot water, were both killed by the hot water treatment. Temperatures $\geq 40^{\circ} \mathrm{C}$ were required to render spores non-viable. Mycelium was equally susceptible to the hot water exposure as conidia and ascospores.

The time-temperature combination for apple scion wood and rootstock disinfection of $N$. ditissima was identified as $50^{\circ} \mathrm{C}$ for 15 to $25 \mathrm{~min}$ HWT. Although this HWT resulted in a complete inactivation of the internal infections, with no internal browning of the wood tissues, none of the propagation material grew when grafted and planted in an orchard. When the HWT was adjusted by reducing the immersion times to 15 and $25 \mathrm{~min}$, there was again no internal browning in the rootstocks or the dormant scion wood. However, after this HWT only $2 \%$ of the propagation material grew when grafted and planted in a commercial nursery orchard. In contrast, Keck et al. (1995) using a moist and a dry heat procedure for disinfection of dormant apple ('Golden Delicious') and pear ('Beurré Hardy') scion wood against Erwinia amylovora observed that most scion wood material maintained under moist conditions in an incubator survived exposure at $45^{\circ} \mathrm{C}$ for up to $7 \mathrm{~h}$, and at $50^{\circ} \mathrm{C}$ for up to $3 \mathrm{~h}$, which resulted in only $25 \%$ failure of grafts of scion wood treated at these effective time-temperature combinations. The difference in the HWT in this study was that the 'Braeburn' scion wood were directly immersed in the hot water, whereas Keck et al. (1995) first wrapped the scion wood in wet cotton cloths (wet heat) and maintained them in an incubator for the temperature-time combinations. It is possible that cultivar response to heat varies, and the effect of HWT on different scion cultivars will need to be examined in further research. The higher percentage of dead plants in this study may be due to the direct exposure of the rootstocks and scion wood to the hot water. The effect of these two different heat disinfection methods on apple wood vigour also warrants further research.

This study confirms the reports by Keck et al. (1995) that direct immersion of scion wood in hot water or incubation in dry heat was harmful to apple and pear plant material. In contrast, in commercial grapevine nurseries, HWT at $50^{\circ} \mathrm{C}$ for $30 \mathrm{~min}$ is commonly recommended as an effective method to control endogenous pathogens in grape cuttings (Waite \& May 2005). The grapevine dormant scion wood is immersed directly in hot water for a given temperature and time without any detrimental effect on scion survival (Waite \& Morton 2007, Gramaje et al. 2014). However using the same technique with apple was found to be detrimental to the wood vigour resulting in graft failure, hence a more refined HWT technique will need to be developed.

In conclusion, apple wood is not as resilient to HWT as some other types of wood from other horticultural crops. Further research is therefore required to determine the thermal tolerance of apple wood to $\mathrm{HWT}$ at $45^{\circ} \mathrm{C}$ for $15 \mathrm{~min}$ or at $40^{\circ} \mathrm{C}$ for $30 \mathrm{~min}$; to determine the optimal temperature and times that can reduce inoculum load; and to reduce the proportion of grafted trees that have latent infections, if it becomes impossible to eliminate European canker completely. This, combined with other management practices, may reduce canker incidence in nursery trees.

\section{ACKNOWLEDGEMENTS}

Thanks to commercial nurseries for collaboration in this project. This work was funded by The New Zealand Institute for Plant \& Food 
Research Ltd and the Agricultural and Marketing Research Development Trust (AGMARDT).

\section{REFERENCES}

Amponsah NT, Walter M, Scheper RWA 2014. Agar media for isolation of Neonectria ditissima from symptomatic and asymptomatic apple tissues and production of infective conidia. New Zealand Plant Protection 67: 116-122

Bazzi C, Stefani E, Gozzi R, Burr TJ, Moore CL, Anaclerio F 1991. Hot-water treatment of dormant grape cuttings: Its effects on Agrobacterium tumefaciens and on grafting and growth of vine. Vitis 30: 177-187.

Burr TJ, Ophel K, Katz BH and Kerr A 1989. Effect of hot water treatment on systemic Agrobacterium tumefaciens biovar 3 in dormant grape cuttings. Plant Disease 73: 242-245.

EFSA PLH Panel (EFSA Panel on Plant Health) 2015. Scientific opinion on hot water treatment of Vitis sp. for Xylella fastidiosa. EFSA Journal 13(9): 4225-4235. doi:10.2903/j. efsa.2015.4225

Fatmi M, Schaad NW and Bolkan HA 1991. Seed treatments tor eradicating Clavibacter michiganensis subsp. michiganensis from naturally infected tomato seeds. Plant Disease 75: 383-385.

Gramaje D, Mañas F, Lerma ML, Muñoz RM, García-Jiménez J, Armengol J 2014. Effect of hot-water treatment on grapevine viability, yield components and composition of must. Australian Journal of Grape and Wine Research 20(1): 144-148.

Honervogt B, Lehmann-Danzinger H 1992. Comparison of thermal and chemical treatment of cotton seed to control bacterial blight (Xanihomonas campestris pv. malvacearum). Journal of Phytopathology 134: 103-109.
Keck M, Chartier R, Zislavsky W, Lecomte P, Paulin P 1995. Heat treatment of plant propagation material for the control of fire blight. Plant Pathology 44: 124-129

Mackay JM and Shipton PJ 1983. Heat treatment of seed tubers for control of potato blackleg (Erwinia carotovora subsp. atroseptica) and other diseases. Plant Pathology 32: 385-393

McCracken AR, Berrie A, Barbara DJ, Locke T, Cooke LR, Phelps K, Swinburne TR, Brown AE, Ellerker B, Langrell SRH (2003) Relative significance of nursery infections and orchard inoculum in the development and spread of apple canker (Nectria galligena) in young orchards Plant Pathology 52, 553-566

Robinson K, Foster G 1987. Control of potato blackleg by tuber pasteurisation: the determination of time-temperature combinations for the inactivation of pectolytic Erwinia. Potato Research 30: 121-125.

Scheper RWA, Pauli E 2013. Neonectria ditissima, development of perithecia in culture. Acta Phytopathologic Sininca 43 (suppl.), page 481. 10th International Congress of Plant Pathology: ICPP 2013, 25-30 August 2013, Bejing, China (Abstract P35.003).

Scheper RWA, Fisher BM, Amponsah NT, Walter M 2014. Effect of culture medium, light and air circulation on sporulation of Neonectria ditissima. New Zealand Plant Protection 67: 123-132

Waite H, Morton L 2007. Hot water treatment, trunk diseases and other critical factors in the production of high-quality grapevine planting material. Phytopathologia Mediterranea, 46: 5-17.

Waite H, May P 2005. The effects of hot water treatment, hydration and order of nursery operations on cuttings of Vitis vinifera cultivars. Phytopathologia Mediterranea 44: 144-152. 